\title{
Penentuan Efisiensi Sel Surya Merk Skytec Solar Model Sip-220 dengan Bantuan Software Logger Pro
}

\author{
Muhammad Subhan \\ $\left.{ }^{1}\right)$ Pendidikan Fisika, STKIP Bima \\ Jl. Tendean Kel. Mande Kota Bima-NTB \\ Surat-e: d.hans2I02@gmail.com
}

\begin{abstract}
ABSTRAK : Penelitian ini dilatarbelakangi oleh pembelajaran fisika tentang konversi energi terbarukan khususnya energi surya dan kurangnya informasi tentang materi ini siswa dan guru kurang memahami metode pengukuran untuk mengetahui kualitas pada suatu sel surya terkait efisiensi dan fill factor, sehingga dalam penelitian dibuat buku suplemen untuk memberi informasi dan pemahaman kepada siswa tentang merancang eksperimen dengan memanfaatkan rangkaian pembagi tegangan dan mampu menggunakan software LoggerPro guna mempermudah perhitungan efisiensi sel surya serta memberi informasi baru kepada siswa tetang konversi energi terbarukan khususnya energi surya.

Penelitian menggunakan metode eksperimen penentuan efisiensi sel surya merk Skytec Sollar Model Sip-220 dengan memanfaatkan rangkaian pembagi tegangan untuk meminimalkan tegangan maksimum dari sel surya supaya terbaca oleh alat sensor voltage probe dan current probe. Data diambil dari salah satu modul surya polikristal berjumlah 72 sel dengan dimensi $0,987 \mathrm{~m} \mathrm{x} \mathrm{1,637} \mathrm{m.} \mathrm{Intensitas} \mathrm{energi} \mathrm{cahaya} \mathrm{matahari} \mathrm{pada} \mathrm{saat}$ penelitian 1052 watt. Arus maksimum (Im) dan tegangan maksimum $(V \mathrm{~m})$ diperoleh dari hasil baca oleh software LoggerPro kemudian arus hubungan singkat (Isc) diperoleh dari intercept kurva sedangkan tegangan rangkaian terbuka (Voc) diperoleh dari titik potong kurva serhadap sumbu x, nilai (Isc) dan (Voc) merupakan hasil fitting data tegangan-arus $\left(V \mathrm{i}, I_{\mathrm{i}}\right)$ menurut persamaan linier $\mathrm{y}=\mathrm{ax}+\mathrm{b}$ pada Microsoft excel $\AA_{\text {. }}$

Hasil penelitian menunjukkan bahwa fill factor yang diperoleh dari masing-masing rangkaian dengan resistor $(\mathrm{R} 1=47 \Omega$, dan $\mathrm{R} 2=120 \Omega$ hasilnya adalah 0,416$),(\mathrm{R} 1=47 \Omega$, dan $\mathrm{R} 2=122 \Omega$ hasilnya adalah 0,624$),(\mathrm{R} 1=47$ $\Omega$, dan R2 = $140 \Omega$ hasilnya adalah 0,770$),(\mathrm{R} 1=47 \Omega$, dan $\mathrm{R} 2=155 \Omega$ hasilnya adalah 0,777$), \mathrm{R} 1=47 \Omega$, dan $\mathrm{R} 2=162 \Omega$ hasilnya adalah 0,769$), \mathrm{R} 1=47 \Omega$, dan $\mathrm{R} 2=169 \Omega$ hasilnya adalah 0,773$),(\mathrm{R} 1=47 \Omega$, dan $\mathrm{R} 2=184$ $\Omega$ hasilnya adalah 0,770$),(\mathrm{R} 1=47 \Omega$, dan $\mathrm{R} 2=191 \Omega$ hasilnya adalah 0,735$)$, dan $(\mathrm{R} 1=47 \Omega$, dan $\mathrm{R} 2=200 \Omega$ hasilnya adalah 0,784 ), dan rata-rata nilai fill factor nya adalah 0,713 sehingga nilai efisiensi sel surya juga didapat secara berurutan 10,28 \%, 13,19\%, 12,66 \%,11,60\%,11,32\%, 10,78\%, 10,78\%, 10,00\% dan 9,31\% dan nilai rata-rata dari efisiensinya $11,1 \%$. Naik turunya nilai efisiensi kemungkinan besar sangat berpengaruh terhadap keadaan atau perubahan naik turunya suhu di sekitar modul akibat dari kecepatan angin dan mendung yang tibatiba.
\end{abstract}

Kata kunci: Efisiensi sel surya, fill factor, Logger Pro, Buku Suplemen

\section{PENDAHULUAN DAN KAJIAN LITERATUR}

Kebutuhan masyarakat terhadap listrik sangat penting dalam kehidpan masyarakat. Pemakaian energy listrik pun semakin lama akan semakin meningkat dan peningkatan ini harus diimbangi oleh penyediaan sumber energy listrik. Namun penyediaan energi listrik saat ini masih mengandalkan PLN tenaga disel yang membutuhkan bahan bakar sehingga ketersediaanya masih terbatas untuk daerah-daerah pedalaman yang jauh dari jangkauan PLN tenaga disel tersebut. Salah satu solusi pemerintah untuk memenuhi terbatasnya jangkauan PLN tenaga disel adalah membangun sumber energy terbarukan.

Pembahasan tentang energi terbarukan dapat mempermudah keterbatasan siswa yang kurang mampu memahami konsep dan pengetahuan siswa tentang konversi energy terbarukan pada energi surya, oleh karena itu untuk memenuhi keterbatasan bagi siswa maka diperlukan buku suplemen pembelajaran untuk memudahkan pemahaman siswa terhadap pokok bahasan sumber energi khususnya pada energi surya. Bagi siswa untuk memahami sel surya yang utama adalah karakteristik dari sel surya itu sendiri yaitu efisiensinya yang merupakan perbandingan antara daya maksimum terhadap daya input cahaya yang masuk ke dalam sel surya dan fill factor-nya yaitu parameter yang menentukan daya maksimum dari sel surya atau didefinisikan sebagai perbandingan daya maksimum dengan tegangan terbuka dan arus hubungan singkat produk dari sel surya. Untuk mengetahui besarnya efisiensi dan fill factor sel surya sangat perlu dibutuhkan data-data yang real dalam mengukur sel surya tersebut. Mementukan efisiensi dan fill factor sel surya dibutuhkan set data tegangan-arus yang cukup dengan beban yang dapat diatur dari minimal sampai maksimal. Beban minimal bertujuan untuk memperoleh arus hubung singkat ( $\left.I_{\text {sc }}\right)$ dari data-data (Ii) sedangkan beban maksimal dimaksudkan untuk memperoleh tegangan terbuka $\left(V_{\text {oc }}\right)$ dari data-data $(V i)$. Set data ini dapat diperoleh untuk daya panas matahari yang konstan atau stabil. Pada kenyataannya untuk memperoleh daya panas matahari yang stabil ini sulit karena perubahan cuaca secara tiba-tiba 
sering terjadi, seperti datangnya mendung yang dibawa angin. Hal ini menyebabkan pengukuran tegangan-arus secara manual tidak dapat terlaksana. Jika akan dilakukan pengukuran dengan beban pada daya matahari yang tetap harus dilakukan dalam waktu yang singkat. Pemakaian beban yang secara cepat dapat dilakukan dengan potensiometer, namun penggunaan beban secara langsung dengan potensiometer tidak dapat dilakukan karena beban tidak mampu menerima besarnya daya listrik yang dihasilkan oleh sel surya (terbakar). Salah satu cara untuk memperoleh data tegangan-arus dengan memanfaatkan potensiometer adalah dengan membuat rangkaian pembagi tegangan sedangkan untuk mendokumentasikan data secara otomatis dengan memanfaatkan sensor tegangan dan arus yang dihubungkan dengan transduser logger pro. Logger pro merupakan software yang memungkinkan computer mengumpulkan data yang dapat dimanfaatkan karena mampu merekam data dalam waktu yang cukup akurat per sekonnya dengan data yang cukup banyak.

\section{Sel Surya}

Sel surya Sel surya adalah alat yang mengubah cahaya menjadi listrik atau sering disebut sel photovoltaic. Kualitas sel surya atau sel PV tergantung pada kemampuan menyerap energi matahari dan mengalirkan arus antara dua lapisan dengan muatan yang berlawanan. Jenis sel surya atau photovoltaik yang digunakan adalah Polycrystalline, jenis ini terbuat dari beberapa batang kristal silikon yang dilebur kemudian dituang dalam cetakan yang umumnya berbentuk persegi, harganya pun menjadi lebih murah dari jenis lain sehingga jenis ini paling banyak dipakai saat ini. Efisiensi pada sel surya senis polycrystallin sekitar $12-15$ $\%[2]$.

\section{Karakteristik Sel Surya}

Karakteristik dari keluaran sel surya biasanya ditentukan oleh parameter-parameter, (1) Arus short circuit $\left(I_{\mathrm{sc}}\right)$ merupakan arus yang melalui sel surya ketika beban dihubung singkat atau tegangan antara sel surya bernilai nol; (2) Tegangan open circuit $\left(V_{\text {oc }}\right)$ merupakan tegangan maksimum yang dapat dipenuhi oleh sel surya dan terjadi ketika arus bernilai nol; (3) Maximum power point (MPP) adalah titik maksimum operasi dimana pengeluaran/output $V_{\text {mp }}$ dan $I_{\text {mp }}$ yang dihasilkan oleh sel surya saat kondisi operasional pada kurva $I-V$. Jumlah daya pada batas maksimum ditentukan dengan mengalikan $V_{\mathrm{mp}}$ dan $I_{\mathrm{mp}}$ maksimum [3]. Untuk melihat karakteristik sel surya dapat diukur antara lain :

1) Fill factor; didefinisikan sebagai perbandingan dari daya maksimum (Pmax) dari sel surya untuk produk $V_{\text {oc }}$ dan $I_{\text {sc }} . V_{\text {oc }}$ dan $I_{\text {sc }}$ yang diperoleh dari data-data $V i, I i$, maka nilai $\left(V_{\mathrm{mp}} I_{\mathrm{mp}}\right)$ lebih kecil dari nilai $V_{\mathrm{oc}}$ dan $I_{\mathrm{sc}}$. Oleh karena itu, fill factor yang paling sering ditentukan dari pengukuran kurva $I-V$ dan didefinisikan sebagai daya maksimum $\left(\mathrm{P}_{\max }\right)$ dibagi dengan daya teoritis $P_{\text {th }}$ atau $\left(\begin{array}{lll}V_{\mathrm{oc}} & I_{\mathrm{sc}}\end{array}\right)$, dengan persamaan untuk fill factor adalah,

$$
f f=\frac{P_{\max }}{V_{o c} I_{s c}}=\frac{V_{m p} I_{m p}}{V_{o c} I_{s c}}
$$

$V_{\text {mp }}$ adalah tegangan dari daya keluaran maksimum, dan $I_{\mathrm{mp}}$ adalah arus dari daya keluaran maksimum. Intensitas cahaya yang diterima oleh sel surya didefinisikan sebagai daya yang diterima dibagi luas penampang sel surya.

$$
I_{\text {cahaya }}=\frac{P_{i n}}{A}
$$

Ketika sel surya dalam kondisi short circuit, arus maksimum atau arus short circuit $\left(I_{\mathrm{sc}}\right)$ dihasilkan, sedangkan pada open circuit arus yang mengalir adalah nol sehingga tegangan maksimum disebut tegangan open circuit $\left(V_{\text {oc }}\right)$, sehingga pada layar Logger Pro akan diperoleh titik-titik data (Vi, Ii). Data-data tersebut dalam ekperimen ini akan di-fitting dengan persamaan linier,

$$
y=a x+b
$$

Dari bentuk persamaan (3) $x=V, y=I, a$, dan $b$ merupakan koefisien fitting. Arus hubungan singkat $\left(I_{\mathrm{sc}}\right)$ diperoleh dari titik potong kurva $x y$, sedangkan tegangan hubung terbuka $\left(V_{\mathrm{oc}}\right)$ diperoleh dari titik potong kurva terhadap sumbu $x$

2) Efisiensi sel surya; efisiensi sel surya didefinisikan sebagai perbandingan daya keluar $\left(P_{\text {out }}\right)$ dengan daya masukan $\left(P_{\text {in }}\right)$. Daya masukan dihitung sebagai daya yang diterima oleh permukaan sel surya. Rumus umum efisiensi adalah

$$
\% \eta=\frac{f f P_{t h}}{P_{i n}} \times I 00
$$

dengan

$$
\begin{aligned}
& P_{\text {th }}=V_{\text {oc }} I_{\text {sc }} \\
& P_{\text {out }}=f f V_{\text {oc }} I_{\mathrm{sc}}
\end{aligned}
$$

Efisiensi $(\eta)$ yang terjadi pada sel surya digambarkan sebagai perbandingan daya listrik maksimum terhadap kekuatan daya yang diterima [4].

\section{Rangkaian Pembagi Tegangan}

Rangakaian pembagi tegangan digunakan untuk memperoleh tegangan yang diinginkan dari suatu sumber tegangan yang besar

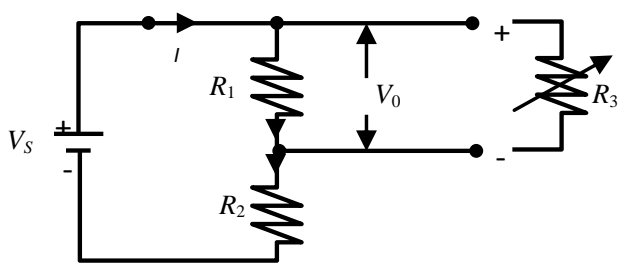

Gambar 1. Rangkaian pembagi tegangan

$$
R=\frac{V}{I}
$$

Untuk mencari nilai resistor parallel

$$
R_{p}=\frac{R_{1} R_{3}}{R_{1}+R_{3}}
$$

Jadi, untuk menentukan $V_{0}$ pada tahanan pengganti paralel untuk rangkaian pada gambar 1 disesuaikan adalah 
$V_{0}=\frac{R_{p}}{\left(R_{p}+R_{2}\right)} V_{S}$ atau $V_{S}=\frac{\left(R_{p}+R_{2}\right)}{R_{p}}$

Untuk mencari daya adalah

$$
P=V I
$$

\section{Logger Pro}

Logger Pro merupakan salah satu softwere yang mempunyai keistimewaan yang mampu menyajikan berupa data kuantitatif dan grafiknya secara simultan dari gejala fisika secara nyata dan memberikan jembatan antara pengamatan langsung dengan representasi abstrak dari berbagai fenomena fisika. Software Logger Pro memungkinkan komputer untuk mengumpulkan data yang banyak persecon-nya. Kegunaan dari software Logger Pro mendukung lebih banyak sensor alat ukur yang tepat waktunya untuk analisis dan grafik. [6].

\section{METODE PENELITIAN}

Metode dalam penelitian ini adalah eksperimen murni. Untuk memperoleh data maka dibutuhkan rangkaian sederhana komponen elektronik.

\section{Alat dan Bahan:}

1. Sel Surya berfungsi sebagai alat pengkonversi radiasi matahari menjadi energi listrik

2. Solar Power Meter TES 1333R berfungsi sebagai alat pengukur intensitas radiasi matahari.

3. Bread bord atau papan rangkaian berfungsi sebagai tempat untuk merangkai komponen-komponen eksperimen.

4. Lab Quest (mini) berfungsi untuk merekam data input dan diteruskan ke Logger Pro sebagai data output.

5. Current probe berfungsi sebagai sensor arus AC dan DC frekuensi rendah.

6. Voletage Probe digunakan dengan LabQuest, untuk mengukur tegangan langsung.

7. Multimeter YX-393 berfungsi sebagai alat yang digunakan untuk mengukur kuat arus listrik yang ada dalam rangkaian tertutup.

8. Komputer Windows XP dengan bantuan software Logger Pro dan software Microsoft Office 2010 (Excel)

9. Resistansi semen berfungsi sebagai hambatan tegangan pada rangkaian eksperimen yang bersumber dari sel surya, resistansi yang digunakan pada penelitian ini bernilai $20 \Omega 20 \mathrm{~W}, 22 \Omega 20 \mathrm{~W}, 47 \Omega 20 \mathrm{~W}, 42 \Omega 20 \mathrm{~W}$, $55,2 \Omega 20 \mathrm{~W}, 120 \Omega 20 \mathrm{~W}$.

10. Potensiometer berfungsi untuk mengatur dan mengendalikan besarnya nilai hambatan, potensiometer yang digunakan dalam penelitian ini bernilai B5K.

11. Kabel capit buaya berfungsi untuk penghubung rangkaian.

\section{Rangkaian Penelitian}

Skema rangkaian penelitian yang digunakan akan dirangkai seperti pada Gambar di bawah ini.

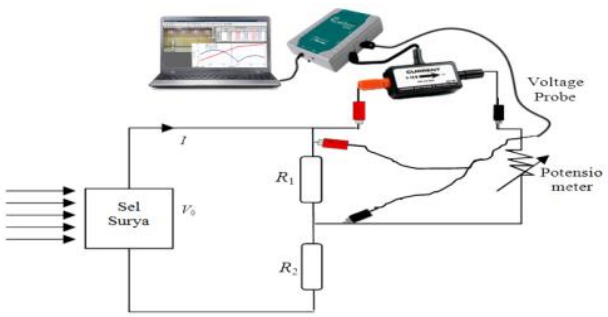

Gambar 2. Unit perangkat dan Rangkaian eksperimen

\section{Metode Analisis Data}

1. Menganalisis rangkaian dengan mengganti variable nilai untuk melihat perbedaan nilai daya masukan, daya dari rangkaian sebagai $P$ in dengan menggunakan persamaan (6), (8), dan (9).

2. Menganalisis titik-titik data (Vi, Ii) dengan melakukan fitting data pada excel yang diperoleh dari layar Logger Pro dengan menggunakan persamaan (4), sehigga diperoleh nilai $V_{\mathrm{oc}}, \mathrm{I}_{\mathrm{sc}}, \mathrm{V}_{\mathrm{m}}$, dan $\mathrm{I}_{\mathrm{m}}$. Menentukan fill Factor dengan persamaan (1), $P_{\text {th }}$ dengan persamaan (5), $\mathrm{P}_{\text {out }}$ dengan persamaan (6) dan Efisiensi dengan menggunakan (4)

\section{HASIL DAN PEMBAHASAN}

Hasil perhitungan dari beberapa variasi resistansi $\left(R_{2}\right)$ dengan $\left(R_{1}\right)$ dan potensiometer yang sama pada tabel (1). Tabel menunjukkah nilai tegangan sumber $\left(V_{\mathrm{s}}\right)$ yang dicari dengan persamaan (9) dapat mewakili teori bahwa dari setiap 1 sel surya menghasilkan lebih kurang 0,5 volt bergantung pada intensitas matahari dan keadaan suhu di sekitar modul sehingga jumlah sel surya yang diteliti dalam 1 modul surya sebanyak 72 sel dan menghasilkan maksimal 36 volt.

Tabel 1. Perhitungan rangkaian pembagi tegangan-arus dan Daya masuk

\begin{tabular}{|c|c|c|c|c|c|c|c|c|c|}
\hline $\begin{array}{c}V_{0} \\
\text { (volt) }\end{array}$ & $\begin{array}{l}I_{3} \\
\text { (A) }\end{array}$ & $\begin{array}{l}R_{1} \\
(\Omega)\end{array}$ & $\begin{array}{l}R_{2} \\
(\Omega)\end{array}$ & $\begin{array}{l}R_{3} \\
(\Omega)\end{array}$ & $\begin{array}{l}R_{P} \\
(\Omega)\end{array}$ & $\begin{array}{c}V \\
\text { (volt) }\end{array}$ & $\begin{array}{l}I_{1} \\
\text { (A) }\end{array}$ & $\begin{array}{c}I \\
\text { (A) }\end{array}$ & $\begin{array}{c}P_{\text {in }}=V . I \\
\text { (watt) }\end{array}$ \\
\hline 8,99 & 0,11 & 47 & 120 & 5000 & 46,562 & 32,151 & 0,19 & 0,30 & 9,62 \\
\hline 9,99 & 0,19 & 47 & 122 & 5000 & 46,562 & 36,165 & 0,21 & 0,41 & 14,70 \\
\hline 8,01 & 0,17 & 47 & 140 & 5000 & 46,562 & 32,094 & 0,17 & 0,34 & 11,05 \\
\hline 7,38 & 0,16 & 47 & 155 & 5000 & 46,562 & 31,937 & 0,16 & 0,32 & 10,09 \\
\hline 7,95 & 0,17 & 47 & 162 & 5000 & 46,562 & 35,595 & 0,17 & 0,34 & 12,18 \\
\hline 7,63 & 0,17 & 47 & 169 & 5000 & 46,562 & 35,325 & 0,16 & 0,33 & 11,56 \\
\hline 7,07 & 0,15 & 47 & 184 & 5000 & 46,562 & 34,989 & 0,15 & 0,30 & 10,54 \\
\hline 6,45 & 0,14 & 47 & 191 & 5000 & 46,562 & 32,900 & 0,14 & 0,28 & 9,19 \\
\hline 6,01 & 0,12 & 47 & 200 & 5000 & 46,562 & 31,827 & 0,13 & 0,25 & 8,02 \\
\hline
\end{tabular}

Tampilan data (Vi, Ii) dan grafik pada Logger Pro untuk tegangan $(V)$ dan arus $(I)$ dimana potensio meter diputar secara perlahan-lahan seperti pada gambar (3)

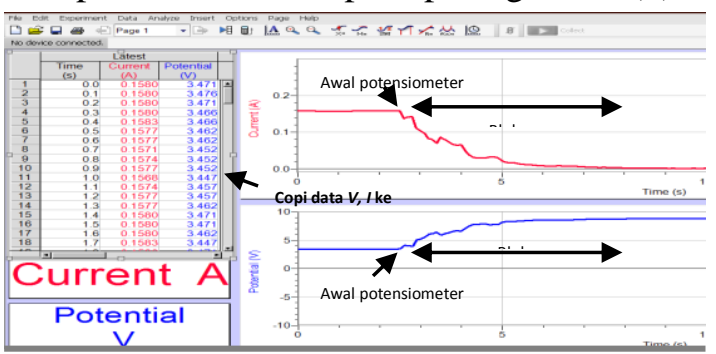

Gambar 3. Tampilan Logger Pro hasil rekaman data $(V \mathrm{i})$ (Ii) 
Berikut sampel tampilan kurva hubungan $V$-I hasil fitting data dengan menggunakan Microsoft Excel $^{\circledR}$ untuk $R 1=47$ $\Omega$ dan $R 2=162 \Omega$ dan potensiometer $5 \mathrm{k} \Omega$ pada Gambar 4

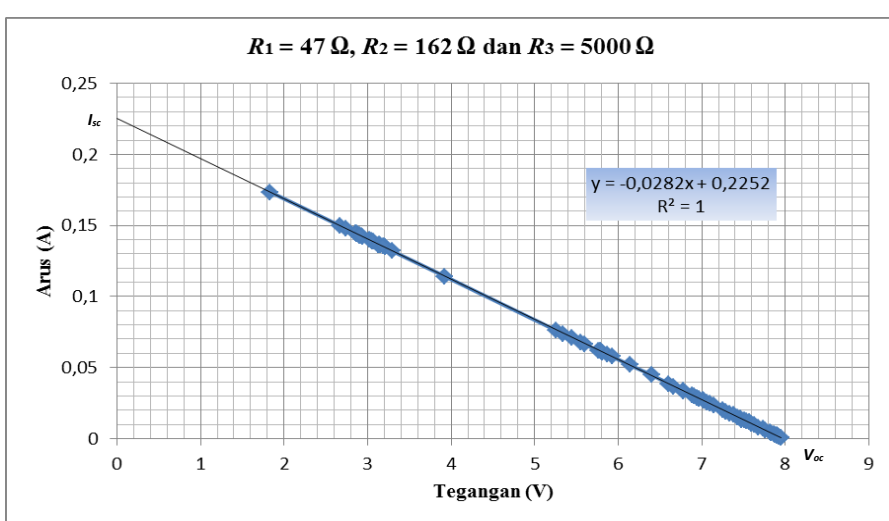

Gambar 4. Kurva hubungan V-I

Grafik hubungan $V$-I dari hasil persamaan fitting Microsoft Excel $^{\circledR}$ persamaan linier $y=a x+b$ dengan nilai $y=$ $0,0282 x+0,2252, y$ adalah arus dan $x$ adalah tegangan sedangkan 0,028 adalah nilai garis singgung (slope) dan 0,225 adalah nilai titik potong (intersept) yang juga sebagai nilai $I_{\mathrm{sc}}$, sehingga $I_{\mathrm{sc}}=0,225 \mathrm{~A}$ dan $V_{\mathrm{oc}}=7,971$ volt hasil perbandingan antara nilai intersept terhadap slope. Sedangkan $R_{2}=1$ merupakan indeks determinan dari masing-masing data tersebut yang berarti diperoleh hubungan yang sangat kuat antara tegangan dan arus, sehingga jika diambil garis kotak-kotak dari grafik maka akan terlihat $V_{\mathrm{m}}$ dan $I_{\mathrm{m}}$ terlihat lebih kecil dari $V_{\mathrm{oc}}$ dan $I_{\mathrm{sc}}$ dapat lihat pada table,

Tabel 2. Nilai $V_{\mathrm{oc}}, I_{\mathrm{sc}}, P_{\mathrm{max}}, P_{\mathrm{th}}, P_{\mathrm{in}}, f f$ dan $\eta$ masing-masing resistansi dengan potensiometer $5 \mathrm{~K}$

\begin{tabular}{|c|c|c|c|c|c|c|c|c|c|c|c|}
\hline \multicolumn{2}{|c|}{ Resistansi $(\Omega)$} & Persamaan & $V_{o c}$ & & & $I_{m}$ & $P_{\text {max }}$ & $P_{t h}$ & $P_{\text {in }}$ & Fill & Efisiensi \\
\hline R1 & R2 & fitting & & (A) & (volt) & (A) & (watt) & (watt) & (watt) & factor & $(\eta) \%$ \\
\hline 47 & 120 & $y=-0,0293 x+0,2643$ & 9,01 & 0,26 & 8,99 & 0,11 & 0,99 & 2,38 & 9,62 & 0,42 & 10,28 \\
\hline 47 & 122 & $y=-0,0309 x+0,3103$ & 10,03 & 0,31 & 9,99 & 0,19 & 1,94 & 3,11 & 14,70 & 0,62 & 13,19 \\
\hline 47 & 140 & $y=-0,0283 x+0,2266$ & 8,01 & 0,23 & 8,01 & 0,17 & 1,40 & 1,82 & 11,05 & 0,77 & 12,66 \\
\hline 47 & 155 & $y=-0,0276 x+0,2038$ & 7,38 & 0,20 & 7,38 & 0,16 & 1,17 & 1,51 & 10,09 & 0,78 & 11,60 \\
\hline 47 & 162 & $y=-0,0282 x+0,2252$ & 7,97 & 0,23 & 7,95 & 0,17 & 1,38 & 1,79 & 12,18 & 0,77 & 11,32 \\
\hline 47 & 169 & $y=-0,0279 x+0,2128$ & 7,63 & 0,21 & 7,63 & 0,16 & 1,26 & 1,63 & 11,65 & 0,77 & 10,78 \\
\hline 47 & 184 & $y=-0,0275 x+0,1948$ & 7,10 & 0,20 & 7,07 & 0,15 & 1,06 & 1,38 & 10,54 & 0,77 & 10,10 \\
\hline 47 & 191 & $y=-0,027 x+0,1837$ & 6,80 & 0,18 & 6,45 & 0,14 & 0,92 & 1,25 & 9,19 & 0,73 & 10,00 \\
\hline 47 & 200 & $y=-0,0263 x+0,1583$ & 6,03 & 0,16 & 6,01 & 0,12 & 0,75 & 0,95 & 8,02 & 0,78 & 9,31 \\
\hline
\end{tabular}

Nilai $V_{\mathrm{m}}$ dan $I_{\mathrm{m}}$ dapat diambil dari titik tegangan dan arus maksimum yang terbaca oleh logger pro. Dari hasil analisis fitting data didapat nilai $V_{\mathrm{oc}}, I_{\mathrm{sc}}, P_{\mathrm{max}}, P_{\mathrm{th}}, P_{\mathrm{in}}, f f$ dan $\eta$ dari beberapa variasi nilai resistansi yang berbeda dengan potensiometer $5 \mathrm{~K}$, dari beberapa urutan hasilnya tidak menunjukkan perbedaan yang begitu jauh, demikian juga nilai efisiensi berkisar 9,31\% sampai dengan 13,19\% naik turun secara acak meskipun nilai resistansinya $R$ berbedabeda, dari hasil penelitian ini dapat dibandingkan dengan efisiensi sel surya polikristal merk Skytec Solar Model Sip220 dari fabrikasinya berkisar antara $12 \%$ sampai $15 \%$, dengan demikian hal ini disebabkan oleh beberapa faktor dari beberapa para meter eksternal seperti keadaan mendung yang menyebabkan naik turunya suhu matahari, kecepatan bertiupnya angin, keadaan atmosfir disebabkan oleh cuaca yang berubah-ubah pada saat melakukan pengukuran.

\section{KESIMPULAN}

Dari penelitian yang telah dilakukan tentang perancangan ekperimen penentuan fill factor dan efisiensi sel surya merk Skytec Solar Model Sip-220 dengan bantuan software Logger Pro di PLTH Pantai Baru Bantul Yogyakarta dapat diambil kesimpulan:

1. Telah dibuat rancangan ekperimen berupa rangkaian pembagi tegangan untuk kebutuhan penelitian yaitu meminimalkan tegangan maksimal dari sel surya supaya mampu dibaca oleh alat pesensor tegangan yang akan dibaca oleh software Logger Pro sebagai data login sehingga penelitian dapat dilakukan dengan waktu lebih singkat dan mendapatkan data yang lebih banyak.

2. Dari hasil penelitian nilai Fill factor didapat nilai ratarata dari variasi nilai resistor $(R)$ yang berbeda pada rangkaian hasilnya adalah 0,713 dan nilai efisiensi rata-ratanya adalah $11,1 \%$. Adapun perbedaan nilai efisiesi dan fill factor sangat berpengaruh terhadap keadaan atau perubahan naik turunya suhu di sekitar modul akibat dari kecepatan angin dan mendung yang tiba-tiba.

3. Buku suplemen tentang perancangan ekperimen penentuan efisiensi sel surya merk Skytec Solar Model Sip-220 dengan bantuan software Logger Pro disimpulkan layak dijadikan bahan ajar siswa untuk materi konversi energi terbarukan pada sel surya dan panduan untuk melakukan percobaan selanjutnya.

\section{DAFTAR PUSTAKA}

[1] Sadiman, A. S. Rahardjo, R. Haryono, A. Rahardjito., Media Pendidikan, PT. Raja Grafindo Persada, 2006.

[2] Sukandar rumidi, Herry, Z. K. Wintolo, D., Energi Terbarukan, Gajah Mada University Press, 2013.

[3] Karina A, Satwiko S. Studi Karakteristik Arus Tegangan (Kurva I-V) pada Sel Tunggal Polikristal Silikon serta Pemodelannya. Prosing XXV HFI Jateng \& DIY, 2012, hal. 163-166.

[4] Toifur, M., Perbaikan Penentuan Nilai Fill Factor SelSurya Dengan Bantuan Fitting Data dan Teknik Modified Regulafalse, UAD, Jurnal, 2013.

[5] Tipler, P. A. (alih bahasa Bambang Soegiyono). Fisika Untuk Sains dan Teknik, Erlangga, 2002.

[6] http://www.vernier.com/products/software/lp/. Diakses tanggal 26 April 2015 